of the Council, as well as a member of others. Yet he found time to be secretary and treasurer of one of the senior actuarial clubs.

What of his personal life? He was devoted to his family, his home and beautiful garden. A lesser known interest involved him in many charitable activities. He was a practical man, in the finest sense, especially in his desire to help the less fortunate in our community. He was the first Honorary Treasurer of the Disablement Income Group, and then for several years a trustee of their charitable trust. The Hydon Hill Cheshire Home and Gosden House School have particular cause to be grateful for his enthusiastic and practical interest. He was also a Governor of Christ's Hospital, and it is significant that his interest in others was most manifest among young pcople; he seemed completely at home in their company.

How then do we sum up the bare half-century of his life? Each of us has his own impression, and I have ventured to articulate those of one of us. Only God can know the complete picture, but individually we see nuany parts. He was a very professional person, yet he had the common touch. His qualities combined to produce a wide ranging capability and a breadth of character that set the kind of example we need among us.

It helps my task to speculate on how he would have wished us now, today, to remember him. I recall some lines written by George Russell because they come so close to my own guess:

When mine hour is come

Let no teardrop fall

And no darkness hover

Round me where I lie.

I think Deg's greatness lay in his modesty. Such was the man for whose life and example we give thanks today.

\title{
HENRY EDWARD MELVILLE
}

H. F. Melvill.e died on Monday, 9 February 1976 at the age of 92 . He qualified as a Fellow in 1908 and prior to his death was the longest qualified survivor. His first senior appointment was as life manager of the Eagle Star.

In 1931 he was appointed Actuary and Secretary to the National Provident Institution, a mutual life office then 95 years old--very sound and reputable, but progressing slowly. Here he was very successful in bringing the office through the years of depression and initiating years of growth with a more dynamic policy.

Perhaps his greatest contribution was to start investment in ordinary shares, not an unknown practice at the time, but regarded as a broad road to disaster by many life companies. In management he was firm but human, and a good trainer of men. His clear brain and devastating criticism of ill-thought-out plans or conduct continued to impress his associates after he retired from managership in 1945; he remained a director of the National Provident for a further 18 years.

He was outstanding in the field of investment and became Deputy Chairman of the Investment Protection Committee of the British Insurance Association in 1938, and Chairman in 1940. He played an important part in protecting the rights of debenture holders and preference shareholders. He was also a member of the Council for Foreign Bondholders from 1940 to 1950 , being asked to remain on the Council after his official retirement from business. He rose to high office in the lnstitute and, after holding all the honorary positions, was elected President in $1942-44$.

He served continuously on conmittees of the Life Offices' Association from 1932 to 1945 , being a member of eleven in all, a number of them concurrently, and was chairman in 1935-6.

Melville expected high standards from those associated with him, and though somewhat forbidding on superficial acquaintance, closer association revealed the humanity in his character that led to admiration and affection. Up to the time of his death, he continued to take an active and enquiring interest in the business world that he had adorned. 